\title{
Diplomasi Digital Sebagai Dampak Pandemi Global Covid-19: Studi Kasus Diplomasi Indonesia Di Perserikatan Bangsa-Bangsa (Pbb)
}

\author{
Muhammad Fikry Anshori \\ Kajian Wilayah Jepang, Sekolah Kajian Stratejik dan Global, Universitas Indonesia \\ muhammad.fikry01@ui.ac.id
}

\begin{abstract}
The background of this article is the existence of a global pandemic COVID-19 which has an impact in various fields. This article seeks to explore the impact of the COVID-19 global pandemic on information and communications technology (ICT) in the form of digital diplomacy. Exploration is carried out by investigating the case of Indonesian diplomacy at the United Nations (UN) in March, April, and May 2020. The main concept in this article is digital diplomacy. This concept illustrates the use of ICT as a means of diplomacy for state actors and changes at the policy and institutional levels. This article found various digital diplomacy activities from the Permanent Mission of the Republic of Indonesia to the United Nations in New York, United States during the global pandemic COVID-19. These activities include: 1) coordination with Indonesia's Embassy and Consulate General in the United States to protect Indonesian citizens; 2) participation in UN Security Council virtual meeting to discuss international peace and security issues; and 3) participation in other UN bodies virtual meetings to discuss international development issues. This article argues that the impact of the COVID-19 global pandemic in the field of ICT is reflected in Indonesia's digital diplomacy at the United Nations. The global pandemic COVID-19 changed the means and tools used by Indonesian diplomats to gather information, negotiations, and responses on international issues. Even so, Indonesian diplomacy at the UN continues to run optimally.
\end{abstract}

Keywords: COVID-19, Digital Diplomacy, Indonesia, Information and Communications Technology (ICT) 


\begin{abstract}
Abstrak
Latar belakang artikel ini adalah keberadaan pandemi global COVID-19 yang memberikan dampak di berbagai bidang. Artikel ini berupaya untuk mengeksplorasi dampak pandemi global COVID-19 pada teknologi informasi dan teknologi (TIK) dalam bentuk diplomasi digital. Eksplorasi dilakukan dengan mengangkat kasus diplomasi Indonesia di Perserikatan Bangsa-Bangsa (PBB) pada bulan Maret, April, dan Mei 2020. Konsep utama dalam artikel ini adalah diplomasi digital. Konsep ini menggambarkan penggunaan TIK sebagai sarana diplomasi bagi aktor negara serta perubahan di tingkat kebijakan dan institusi. Artikel ini menemukan beragam aktivitas diplomasi digital dari Perutusan Tetap Republik Indonesia (PTRI) untuk PBB di New York, Amerika Serikat ketika pandemi global COVID-19. Aktivitas tersebut antara lain: 1) koordinasi dengan Kedutaan Besar dan Konsulat Jenderal Republik Indonesia di Amerika Serikat untuk melindungi warga negera Indonesia (WNI); 2) partisipasi dalam pertemuan virtual Dewan Keamanan (DK) PBB untuk membahas isu keamanan dan perdamaian internasional; serta 3) partisipasi dalam pertemuan virtual organ PBB lainnya untuk membahas isu pembangunan internasional. Artikel ini berpendapat dampak pandemi global COVID-19 di bidang TIK tergambarkan dalam diplomasi digital Indonesia di PBB. Pandemi global COVID-19 mengubah sarana dan alat yang digunakan diplomatdiplomat Indonesia untuk mengumpulkan informasi, negosiasi, dan respons terkait isu internasional. Walaupun begitu, diplomasi Indonesia di PBB tetap berjalan optimal.
\end{abstract}

Kata kunci: : COVID-19, Diplomasi Digital, Indonesia, Perserikatan Bangsa-Bangsa (PBB), Teknologi Informasi dan Komunikasi (TIK) 


\section{Pendahuluan}

COVID-19 adalah penyakit menular yang disebabkan oleh virus corona jenis baru (World Health Organization, 2020a). COVID-19 pertama kali dideteksi di Wuhan, China pada akhir tahun 2019 dan dilaporkan sebagai penyakit yang menyerang sistem pernafasan manusia (World Health Organization, 2020a). Gejala penyakit COVID-19 yang paling umum antara lain demam, rasa lelah, dan batuk kering (World Health Organization, 2020a). Lebih lanjut, penderita COVID-19 mengalami juga rasa nyeri dan sakit di tubuh, hidung tersumbat, pilek, sakit tenggorokan atau diare yang muncul secara bertahap (World Health Organization, 2020a). Sampai tanggal 22 Mei 2020, World Health Organization (2020b) mencatat ada 4,9 juta kasus penderita COVID-19 yang sudah terkonfirmasi. Pada periode yang sama, COVID-19 telah memakan korban jiwa sebanyak 327 ribu orang (World Health Organization, 2020b).

Keberadaan COVID-19 yang sudah menjadi pandemi global telah berdampak di bidang ekonomi. COVID-19 menyebabkan pertumbuhan ekonomi dunia menjadi dalam ketidakpastian (Organisation for Economic Co-operation and Development, 2020). Gross Domestic Product (GDP) negara-negara di dunia diperkirakan turun sebanyak $2,4 \%$ di tahun 2020 (Organisation for Economic Cooperation and Development, 2020). Dengan hal tersebut, pertumbuhan ekonomi dunia akan lebih rendah $0,5 \%$ dibandingkan tahun lalu (Organisation for Economic Co-operation and Development, 2020). Lebih lanjut, COVID-19 memberikan dampak berupa gangguan pada sektor keuangan, pariwisata, dan rantai suplai global terutama bagi negaranegara yang saling terhubung dengan China (Organisation for Economic Cooperation and Development, 2020). Dampak ekonomi yang ditimbulkan oleh COVID-19 diprediksi baru dapat diatasi pada tahun 2021 ketika pertumbuhan GDP global sudah pulih menjadi $3,25 \%$ (Organisation for Economic Co-operation and Development, 2020). Namun, jika pandemi global COVID-19 tetap parah maka pertumbuhan ekonomi global akan turun $1,5 \%$ di tahun 2020 (Organisation for Economic Co-operation and Development, 2020).

Walaupun menghadirkan berbagai tantangan di bidang ekonomi, pandemi global COVID-19 juga menghadirkan berbagai kesempatan dalam penggunaan teknologi informasi dan komunikasi (TIK) 
(Vieru et al, 2020). Pandemi ini mendukung terjadinya akselerasi perubahan berbagai aktivitas menjadi berbasis daring melalui penggunaan media sosial dan sebagainya (Vieru et al, 2020). TIK menurut Vieru et al (2020) menjadi lebih cepat diadaptasi pada masa pandemi ini untuk mengatasi kendala mobilitas manusia dan informasi. Lebih lanjut, kecapakan dalam penggunaan TIK menjadi hal yang penting di masa pandemi karena menjamin individu dan kelompok dari berbagai sektor tetap beroperasi (Vieru et al, 2020). Berbagai strategi jangka pendek maupun jangka panjang telah disusun untuk melaksanakan berbagai aktivitas secara daring dengan optimal (Vieru et al, 2020). Singkatnya, penyebaran COVID-19 secara global telah membuat aktivitas berbasis daring menjadi krusial di bandingkan periode sebelumnya (Vieru et al, 2020).

Artikel ini membahas diplomasi digital sebagai dampak pandemi global COVID-19 di bidang TIK. Pembahasan dilakukan dengan mengangkat kasus diplomasi Indonesia di Perserikatan Bangsa-Bangsa (PBB) pada tahun 2020. Selain karena pandemi global COVID-19, kasus ini juga diangkat dengan alasan Indonesia menjadi anggota tidak tetap di Dewan Keamanan (DK) PBB untuk periode 1 Januari 2019 hingga 31 Desember 2020 (Kementerian Luar Negeri Republik Indonesia, 2019a). Dalam membahas kasus tersebut, artikel ini menyaikan terlebih dahulu konsep diplomasi digital. Kemudian, penggambaran mengenai Indonesia dan diplomasi digital di PBB ketika pandemi global COVID-19. Terakhir, artikel ini ditutup dengan simpulan.

\section{Diplomasi Digital}

Jönsson (2012) menyatakan istilah diplomasi sering digunakan dengan pemaknaan yang berbeda-beda. Diplomasi dapat merujuk pada konten hubungan luar negeri secara menyeluruh (Jönsson, 2012). Pengguna istilah tersebut kurang lebih menganggap diplomasi sama dengan kebijakan luar negeri (Jönsson, 2012). Kemudian, ada juga yang mengkonotasikan diplomasi sebagai pelaksanaan kebijakan luar negeri (Jönsson, 2012). Pemaknaan tersebut menempatkan diplomasi sebagai sinonim dari keterampilan negarawan (statecraft) (Jönsson, 2012). Selanjutnya, isitlah diplomasi digunakan untuk menggambarkan pengelolaan hubungan internasional dengan negosiasi (Jönsson, 2012). Negosiasi dianggap sebagai aspek kunci dari diplomasi yang berbeda dengan bentuk interaksi lainnya (Jönsson, 2012). 
Terakhir, istilah diplomasi secara sederhana diartikan sebagai penggunaan dan pengalaman diplomat (Jönsson, 2012). Diplomat adalah individu yang secara resmi mewakili suatu negara untuk menjalin hubungan dengan negara lain (Jönsson, 2012).

\section{Diplomasi berurusan dengan} pengelolaan hubungan antara negaranegara dan antara negara dengan aktor non-negara (Barston, 2013). Diplomasi bagi suatu negara adalah pertimbangan, penyusunan, dan pelaksanaan kebijakan luar negeri (Barston, 2013). Negara menjalankan diplomasi dengan aktor lain untuk menyampaikan, mengkoordinasikan, dan melindungi kepentingan melalui penggunaan korespondensi, perbincangan personal, pertukaran pandangan, lobi, kunjungan, dan aktivitas terkait lainnya (Barston, 2013). Barston (2013) menyatakan fungsi diplomasi dapat dibagi menjadi enam jenis: 1) seremonial, 2) pengelolaan, 3) informasi dan komunikasi, 4) negosiasi internasional, 5) perlindungan, dan 6) kontribusi untuk tatanan internasional. Signifikansi dari setiap fungsi beragam dari satu negara ke negara lain sesuai dengan sumber daya dan keaktifan dalam hubungan internasional (Barston, 2013). Lebih lanjut, setiap fungsi diplomasi bergantung juga pada perkembangan peristiwa dan isu internasional (Barston, 2013).

Diplomasi adalah proses negosiasi dan komunikasi antar negara dengan tujuan menyelesaikan konflik tanpa menggunakan perang (Heywood, 2011). Diplomasi juga adalah salah satu instrumen dari kebijakan luar negeri (Heywood, 2011). Diplomasi adalah bagian tidak terpisahkan dalam politik internasional karena menjadi bentuk interaksi negara yang utama (Heywood, 2011). Segala aktivitas dalam politik internasional memberikan implikasi pada sistem internasional yang terdiri dari negara-negara berdaulat sebagai entitas independen dan otonom (Heywood, 2011). Selain itu, diplomasi menjadi bagian penting dalam organisasi internasional (Heywood, 2011). Organisasi internasional adalah institusi dengan prosedur formal dan keanggotaan yang terdiri dari minimal tiga negara (Heywood, 2011). Keberadaan organisasi internasional memfasilitasi negara-negara suatu arena permanen untuk melakukan diplomasi (Heywood, 2011). Diplomasi tersebut dapat berupa perdebatan isu, pertukaran informasi, penjajakan kesepakatan, dan sebagainya (Heywood, 2011).

Diplomasi menurut Bjola dan Kornprobst (2018) memiliki tiga fitur 
kunci. Pertama, diplomasi pada tingkatan sangat mendasar adalah komunikasi (Bjola \& Kornprobst, 2018). Bentuk komunikasi dalam diplomasi sangat terinstitusionalisasi karena terdapat aturan dan norma yang berlaku (Bjola \& Kornprobst, 2018). Komunikasi tidak terlepas dari diplomasi karena berkutat pada dialog antara diplomat (Bjola \& Kornprobst, 2018). Kedua, aktivitas diplomasi berlangsung dari proses pengakuan ganda antar aktor dalam hubungan internasional (Bjola \& Kornprobst, 2018). Suatu aktor secara resmi dapat melakukan diplomasi ketika sudah diakui sebagai entitas oleh aktor yang sudah diakui sebelumnya (Bjola \& Kornprobst, 2018). Ketiga, diplomasi bertujuan untuk mengelola kemaslahatan bersama seperti keamanan, ekonomi, dan kesehatan (Bjola \& Kornprobst, 2018). Diplomasi menjadi sarana untuk menghasilkan, mendistribusikan, dan memprioritaskan kemaslahatan bersama tersebut bagi komunitas global (Bjola \& Kornprobst, 2018).

Perkembangan teknologi informasi dan komunikasi sudah menghadirkan konektivitas global yang mendukung praktik diplomasi menjadi lebih efektif dan inovatif (Gilboa, 2016). Konektivitas ini memfasilitasi komunikasi dua arah antara pemerintah dengan pemerintah serta pemerintah dengan publik asing (Gilboa, 2016). Diplomat pada saat ini dapat menjangkau dan melibatkan diri ke audiens yang lebih luas dengan teknologi informasi dan komunikasi (Gilboa, 2016). Diplomat dapat lebih menyimak harapan, pujian, kritik, dan saran dari audiens dalam negeri dan luar negeri terkait isu internasional (Gilboa, 2016). Pada saat ini, pemerintah dari berbagai negara sedang melakukan penyesuaian diri dalam memanfaatkan teknologi informasi dan komunikasi untuk pelaksanaan hubungan luar negeri (Gilboa, 2016). Berbagai hal tersebut mengarahkan pada pembuatan dan pengembangan diplomasi digital (Gilboa, 2016).

Diplomasi digital secara luas didefinisikan sebagai penggunaan teknologi informasi dan komunikasi berbasis internet untuk membantu aktor negara dan non-negara dalam pengelolaan dinamika internasional (Bjola, 2015). Teknologi informasi dan komunikasi berbasis internet yang dimaksud dapat berupa konferensi video daring hingga media sosial (Bjola, 2016). Istilah diplomasi digital sering dipertukarkan penggunaannya dengan e-diplomasi (Bjola, 2016). Namun, Bjola (2016) menyatakan kata digital dalam diplomasi 
digital merujuk pada media komunikasi berbasis internet. Sedangkan e-diplomasi merujuk pada penggunaan media komunikasi berbasis elektronik seperti radio dan televisi yang berbeda dengan bentuk komunikasi tradisional seperti surat (Bjola, 2016). Dengan kata lain, penggunaan kata digital dalam diplomasi digital menandakan keberbedaan antara media komunikasi berbasis internet dengan media komunikasi berbasis elektronik pada umumnya (Bjola, 2016).

\section{Holmes (2016a) menyatakan} diplomasi digital terdiri dari tiga komponen utama. Pertama, diplomasi digital merujuk pada cara aktor terlibat dengan audiens luar dengan tujuan menyampaikan pesan atau citra tertentu (Holmes, 2016a). Komponen pertama berkaitan dengan relasi antar aktor atau ke publik asing dari negara yang berbeda (Holmes, 2016a). Kedua, diplomasi digital berhubungan dengan aksesibilitas informasi sebagai sumber daya diplomasi (Holmes, 2016a). Kementerian luar negeri beserta badan pemerintah atau swasta terkait perlu memiliki struktur dan organisasi yang dapat mengelola informasi bagi diplomat agar menjalankan diplomasi digital secara efektif (Holmes, 2016a). Ketiga, diplomasi digital merujuk pada aktivitas analisis data mengenai isu internasional (Holmes, 2016a). Dalam diplomasi digital, aktor perlu memperoleh dan mengolah data untuk memantau berbagai dinamika internasional berdasarkan struktur politik atau opini publik (Holmes, 2016a).

Diplomasi digital menurut Sotiriu (2016) menjanjikan beberapa hal yang tidak dapat dilakukan dengan mudah oleh diplomasi tradisional. Pertama, diplomas digital memungkinkan partisipasi dan kepentingan yang lebih luas dalam pembuatan kebijakan luar negeri (Sotiriu, 2016). Kedua, diplomasi digital memperluas arena untuk mempromosikan negara secara global (Sotiriu, 2016). Ketiga, diplomasi digital meningkatkan popularitas diplomat sebagai pengirim pesan nasional bagi kebijakan negara asal (Sotiriu, 2016). Keempat, diplomasi digital memfasilitasi akuisisi dan distribusi pengetahuan di kalangan remaja (Sotiriu, 2016). Walaupun menjanjikan hal demikian, Sotiriu (2016) berpendapat diplomasi digital memiliki hambatan tersendiri. Pertama, diplomasi digital menghadapi tantangan reliabilitas dalam memberikan dampak jangka pendek dan jangka panjang (Sotiriu, 2016). Negara yang menjalankan diplomasi digital hanya memiliki tolak ukur tidak lebih dari konektivitas dan keaktifan pengguna 
media sosial (Sotiriu, 2016). Dua hal ini tidak dapat menggambarkan dengan baik kemampuan negara dalam diplomasi digital (Sotiriu, 2016).

Holmes (2016b) berpendapat ada dua hal yang sangat menggambarkan diplomasi digital. Pertama, diplomasi digital pada tingkat kebijakan menunjukan dampak media sosial terhadap cara diplomat melakukan pekerjaannya (Holmes, 2016b). Diplomasi digital mengubah cara pengumpulan informasi, negosiasi, respon sehari-hari, serta praktik diplomasi di masa mendatang (Holmes, 2016b). Berbagai hal ini memungkinkan diplomat melakukan evaluasi terhadap cara merespon dan memprediksi dinamika internasional dengan sarana digital (Holmes, 2016b). Kedua, diplomasi digital pada tingkat institusi menghadirkan transformasi tata kelola (Holmes, 2016b).

Dari kementerian luar negeri, kantor kedutaan, hingga organisasi internasional sedang dibentuk ulang dengan dijalankannya diplomasi digital (Holmes, 2016b). Dengan penggambaran ini, Holmes (2016b) menyatakan diplomasi digital tidak akan pernah hilang hingga masa mendatang. Digital diplomasi perlu dijalankan negara dengan tetap mempertimbangkan pembiayaan dan keuntunganya (Holmes, 2016b). Selain itu, aspek keterbukaan dan kerahasiaan di tengah data yang melimpah di internet perlu diperhatikan negara dalam menjalankan diplomasi digital (Holmes, 2016b).

\section{Indonesia dan Diplomasi Digital di PBB ketika Pandemi Global COVID-19}

$\begin{array}{crrr}c & \text { Perutusan } & \text { Tetap } & \text { Republik } \\ \text { Indonesia (PTRI) } & \text { untuk } & \text { Perserikatan }\end{array}$
Bangsa-Bangsa (PBB) di New York mulai mengambil langkah mitigasi resiko COVID-19 di New York, Amerika Serikat pada tanggal 13 Maret 2020 (indonesiaunny, 2020a). Langkah tersebut sejalan dengan rekomendasi dari PBB yang disampaikan oleh Antonio Guterres, Sekretaris Jenderal PBB, terkait COVID19 sebagai pandemi global (indonesiaunny, 2020a). PBB memberitahukan COVID-19 sudah menjadi krisis yang memberikan dampak bagi semua orang dan perlu keterlibatan berbagai pihak agar ancaman tersebut dapat diatasi bersama-sama (indonesiaunny, 2020a). PTRI untuk PBB di New York menyampaikan juga seluruh staf mereka akan bekerja di rumah kecuali bagi personil penting (indonesiaunny, 2020a). Walaupun dengan kondisi seperti ini, mereka memastikan seluruh pekerjaan yang diperlukan selalu ditangani secara efektif (indonesiaunny, 2020a). 
Aktivitas PTRI untuk PBB di New

York berubah menjadi jarak jauh atau teleworking (indonesiaunny, 2020b). Duta Besar Dian Triansyah Djani, para Deputi Perwakilan Tetap, dan seluruh staf telah menjalankan pekerjaan dengan menggunakan konferensi video daring sejak 10 Maret 2020 (indonesiaunny, 2020b). Pada teleworking 17 Maret 2020, pertemuan mereka membahas tentang laporan perkembangan COVID-19 di Kota New York dan tugas di PBB (indonesiaunny, 2020b). Pembahasan COVID-19 difokuskan pada kondisi warga negara Indonesia (WNI) di Kota New York dan sekitarnya (indonesiaunny, 2020b). Pembahasan tugas di PBB berkaitan dengan persiapan pertemuan Dewan Keamanan (DK) PBB yang akan diadakan secara daring (indonesiaunny, 2020b). Aspek yang menjadi perhatian dalam pembahasan tersebut adalah negosiasi mekanisme pertemuan DK PBB secara daring serta substansi yang akan dibahas (indonesiaunny, 2020b). Duta Besar Dian Triansyah Djani menyatakan pekerjaan tetap berjalan sesuai dengan tugas pokok dan mandat yang diberikan pada PTRI untuk PBB di New York (indonesiaunny, 2020b). Pekerjaan tetap dijalankan dengan melihat situasi dan kondisi COVID-19 di Kota New York tanpa mengurangi tugas dan tanggung jawab (indonesiaunny, 2020b).

Prioritas utama PTRI untuk PBB di New York ketika pandemi global COVID19 adalah perlindungan WNI di Amerika Serikat (indonesiaunny, 2020c). Pada tanggal 18 Maret 2020, seluruh perwakilan Indonesia di Amerika Serikat bersamasama melakukan koordinasi untuk menanggapi dan meminimalisasi dampak penyebaran COVID-19 di Amerika Serikat (indonesiaunny, 2020c). Selain PTRI untuk PBB di New York, ada enam perwaklian Indonesia di Amerika Serikat yaitu Keduataan Besar Republik Indonesia (KBRI) di Washington DC, Konsulat Jenderal Republik Indonesia (KJRI) New York, KJRI Los Angeles, KJRI Chicago, KJRI San Francisco, dan KJRI Houston (indonesiaunny, 2020c). Perlindungan WNI di luar negeri ketika COVID-19 dijalankan dengan menggunakan hotline perwakilan Indonesia serta aplikasi digital bernama safe-travel (Kementerian Luar Negeri Republik Indonesia, 2020a). Aplikasi tersebut menyajikan berbagai pemberitahuan dan informasi yang diperlukan WNI selama di luar negeri (Kementerian Luar Negeri Republik Indonesia, 2020a).

Partisipasi pertama kali Indonesia dalam pertemuan dengan negara anggota 
PBB lainnya secara daring berlangsung juga pada tanggal 18 Maret 2020 (indonesiaunny, 2020d). Pertemuan ini berupa telekonferensi video anggota Komite Kelima pada Anggaran dan Administrasi PBB untuk membahas isu anggaran dan transparansi PBB (indonesiaunny, 2020d). Isu ini berkaitan dengan perencanaan dan penyusunan alokasi anggaran program-program yang fokus pada prioritas stratejik dan reforrmasi PBB (United Nations, 2019a). Hari berikutnya, Indonesia berpartisipasi dalam koordinasi daring bersama negaranegara G-77 dan China terkait penguatan United Nations Economic and Social Council (ECOSOC) dan implementasi Agenda 2030 (indonesiaunny, 2020e). Agenda 2030 adalah rencana aksi pembangunan berkelanjutan guna menciptakan dunia yang menghargai hak asasi manusia, martabat manusia, hukum, keadilan, kesetaraan, dan non-diskriminasi secara universal (United Nations, 2019b). Agenda ini berupaya untuk mengentaskan kemiskinan dalam berbagai bentuk, merealisasikan hask asasi bagi semua, dan mencapai keseteraan gender (Unites Nations, 2019b).

Diplomasi digital Indonesia berikutnya berlangsung dalam pertemuan informal Kelompok Kerja Perlucutan
Senjata yang beranggotakan negara-negara Gerakan Non-Blok

(GNB) (indonesiaunny, 2020f). Indonesia selaku pimpinan pertemuan virtual tersebut membahas tentang isu nuklir serta keamanan siber dan ruang angkasa (indonesiaunny, 2020f). Indonesia mendorong agar negara-negara GNB memiliki posisi yang sama di PBB terkait isu tersebut (indonesiaunny, 2020f). Pada pertemuan selanjutnya yang diadakan tanggal 24 Maret 2020, Indonesia sebagai Koordinator Kelompok Kerja GNB pada Perlucutan Senjata kembali berdiskusi secara informal terkait United Nations Open-Ended Working Group (UN OEWG) dan Non-Proliferation Treaty (NPT) (indonesiaunny, 2020g). UN OEWG adalah kelompok kerja yang bertugas untuk membahas isu siber internasional yaitu: 1) ancaman siber; 2) hukum internasional di ruang siber; 3) aturan, norma, dan prinsip negara di ruang siber; serta 4) pembangunan kapasitas dan kepercayaan diri negara di ruang siber (GIP Digital Watch, 2020). Sedangkan NPT adalah perjanjian internasional untuk membatasi penggunaan persenjataan dan teknologi nuklir (United Nations, 2019c).

Pada tanggal 2 April 2020, Indonesia berhasil meloloskan resolusi Majelis Umum PBB tentang solidaritas 
global untuk mengatasi COVID-19 (indonesiaunny, 2020h). Indonesia adalah inisiator resolusi bersama dengan Ghana, Liechtenstein, Norwegia, Singapura, dan Swiss (inonesiaunny, 2020h). Lalu, ada 188 negara yang menjadi ko-sponsor dalam resolusi tersebut (indonesiaunny, 2020h). Resolusi dengan judul "Global Solidarity to Fight COVID-19" ini adalah resolusi pertama yang diterbitkan oleh PBB terkait COVID-19 sejak pengumuman status pandemi global oleh World Health Organization (WHO) pada tanggal 11 Maret 2020 (Kementerian Luar Negeri Republik Indonesia, 2020b). Secara umum resolusi tersebut menyampaikan pesan politik tentang pentingnya persatuan, solidaritas, dan kerja sama internasional dalam upaya mitigasi pandemi global COVID-19 (Kementerian Luar Negeri Republik Indonesia, 2020b; United Nations, 2020a). Selain itu, ada pesan bela sungkawa bagi bagi keluarga yang menjadi korban COVID-19 serta penghormatan bagi tenaga medis di lapangan (Unites Nations, 2020a). Resolusi ini juga menyampaikan pesan bagi dunia yaitu PBB sebagai organisasi universal memiliki peran penting dalam mengkoordinasikan respons global serta memberikan harapan bagi komunitas internasional dengan kerja sama setiap negara (Kementerian Luar Negeri
Republik Indonesia, 2020b; United Nations, 2020a). Lebih lanjut, peran PBB dicerminkan dalam resolusi berupa inisiatif kerja sama antar negara untuk menghentikan penyebaran COVID-19, mitigasi dampak melalui pertukaran informasi dan kolaborasi ilmuwan, serta penekanan WHO sebagai pelopor koordinasi setiap elemen dalam komunitas internasional (Kementerian Luar Negeri Repubik Indonesia, 2020b; United Nations, 2020a).

Sekretaris Jenderal PBB Antonio Guterres mengajak genjatan senjata global untuk konflik yang sedang berlangsung di seluruh dunia pada tanggal 23 Maret 2020 (United Nations, 2020b). Ajakan tersebut diajukan karena pandemi global COVID19 adalah ancaman bersama bagi seluruh bangsa, etnis, dan kepercayaan (United Nations, 2020b). Keberadaan konflik bersenjata di tengah pandemi global menimbulkan korban bagi pihak yang paling rentan seperti perempuan, anakanak, orang dengan disabilitas, orang termarjinalkan, dan pengungsi (United Nations, 2020b). Lebih lanjut, keberadaan dua hal tersebut juga mendorong kehancuran bagi sistem kesehatan di berbagai negara (United Nations, 2020b). Pada tanggal 6 April 2020, sebanyak 59 negara termasuk Indonesia menyampaikan 
kesetujuan dan dukungan terhadap ajakan Sekretaris Jenderal PBB untuk genjatan senjata global (indonesiaunny, 2020i). 59 negara ini menyatakan kesadaran untuk mengesampingkan konflik bersenjata dan bersama-sama fokus menghadapi ancaman COVID-19 (indonesiaunny, 2020i). Kemudian, negara-negara tersebut menyatakan juga pentingnya bantuan dan perlindungan kemanusiaan bagi warga sipil yang terdampak konflik dan pandemi (indonesiaunny, 2020i). Duta Besar Dian Triansyah Djani menegaskan kembali dukungan bagi ajakan gencatan senjata global dari Sekretaris Jenderal PBB dalam pertemuan DK PBB secara daring pada tanggal 9 April 2020 (Lihat Gambar 1) (indonesiaunny, 2020j). Indonesia menyatakan juga perlunya DK $\mathrm{PBB}$ menunjukan kesatuan dalam mengatasi dampak pandemi global COVID-19 terhadap perdamaian dan keamanan internasional (indonesiaunny, 2020j). Indonesia menambahkan DK PBB perlu menjamin situasi pandemi ini tidak mengganggu kegiatan PBB untuk perdamaian dan keamanan internasional seperti operasi jaga damai dan pengiriman bantuan kemanusiaan di daerah konflik (indonesiaunny, 2020j).

\section{Gambar 1. Duta Besar Dian Triansyah \\ Djani (kanan) dalam pertemuan virtual DK PBB}

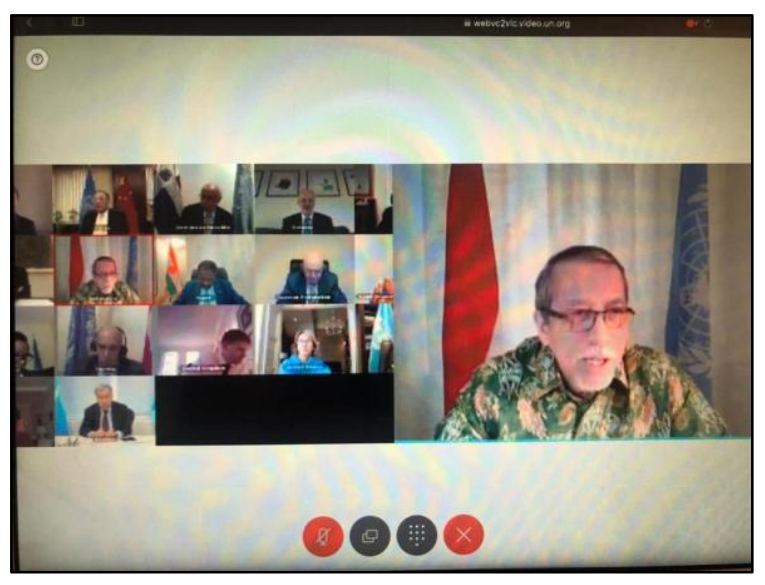

Sumber: indonesiaunny, 2020j

Indonesia menjalankan diplomasi digital melalui pertemuan virtual DK PBB pada tanggal 21 April 2020 yang membahas tentang kelaparan akibat konflik bersenjata (Kementerian Luar Negeri Republik Indonesia, 2020c). Pertemuan ini diinisiasikan oleh Republik Dominika selaku Presiden DK PBB periode April 2020 setelah pengarahan dari Direktur Jenderal Food and Agriculture Organization (FAO) (Kementerian Luar Negeri Republik Indonesia, 2020c). Dalam pertemuan tersebut, Indonesia menyampaikan tiga poin utama: 1) kelaparan tidak boleh digunakan sebagai metode pertempuran; 2) kerja sama internasional penting dalam melindungi warga sipil; serta 3) langkah untuk melindungi warga sipil harus dijalankan melalui serangkaian perdamaian yaitu dari 
pencegahan konflik, jaga damai, bangun damai, dan pembangunan berkelanjutan (Kementerian Luar Negeri Republik Indonesia, 2020d). Hasil pertemuan mengenai kelaparan akibat konflik bersenjata adalah diadopsinya Pernyataan Presiden DK PBB pada tanggal 29 April 2020 (indonesiaunny, 2020k). Pernyataan tersebut berisi beberapa hal: 1) mengingatkan hubungan antara konflik bersenjata, kekerasan dan kerawanan pangan, dan ancaman kelaparan; 2) menegaskan pentingnya seluruh pihak yang berkonflik untuk menghormati prinsip humaniter dalam pemberian bantuan kemanusiaan; serta 3) mendorong PBB dan pemangku kepentingan terkait untuk bekerja sama dalam membantu warga sipil dan negara yang terdampak konflik guna mencapai agenda pembangunan berkelanjutan (indonesiaunny, 2020k). Indonesia selaku anggota tidak tetap DK PBB mendukung diadopsinya pernyataan tersebut (indonesiaunny, 2020k).

\section{United Nations Development} Programme (UNDP) mengadakan pertemuan virtual untuk membahas respons terhadap pandemi global COVID19 di kawasan Asia dan Pasifik pada tanggal 13 Mei 2020 (Kementerian Luar Negeri Republik Indonesia, 2020e). Dalam pertemuan

tersebut

Duta

Besar

Mohammad Koba selaku Deputi Wakil Tetap Indonesia untuk PBB menyampaikan apresiasi bagi UNDP atas upaya yang dilakukan dalam menghadapi pandemi ini (Kementerian Luar Negeri Republik Indonesia, 2020e). Kemudian, Indonesia juga menekankan perencanaan dan pendanaan sebagai hal penting untuk membantu negara anggota PBB dalam mengatasi tantangan COVID-19 (Kementerian Luar Negeri Republik Indonesia, 2020e). Pertemuan ini juga membahas berbagai upaya pemulihan dampak pandemi global dengan inovasi pendidikan dan kesehatan digital di kawasan Asia dan Pasifik (Kementerian Luar Negeri Republik Indonesia, 2020e). Ke depannya, upaya pemulihan akan dijalankan dengan mempertimbangkan aspek perubahan iklim dan lingkungan hidup guna mendukung aktivitas ketika dan pasca pandemi global (Kementerian Luar Negeri Republik Indonesia, 2020e).

$$
\text { Pada tanggal } 19 \text { Mei 2020, }
$$
Indonesia berpartisipasi dalam pertemuan virtual ECOSOC Operational Activities Segment (OAS) untuk mendiskusikan laporan Sekretaris Jenderal PBB terkait Quadrennial Comprehensive Policy Review (QCPR) dan United Nations Development System (UNDS) 
(Kementerian Luar Negeri Republik Indonesia, 2020f). QCPR adalah mekanisme untuk menilai keefektifan, efisiensi, koherensi, dan dampak dari aktivitas operasional PBB dalam pembangunan internasional (United Nations, 2020c). Sedangkan UNDS adalah cara kerja PBB untuk membantu negaranegara dalam mencapai pembangunan berkelanjutan (United Nations, 2020d). Duta Besar Mohammad Koba menekankan tiga hal dalam pertemuan tersebut: 1) UNDP harus mengumpulkan seluruh sumber daya secara terkoordinasi dan terintegrasi untuk mempercepat implementasi pembangunan berkelanjutan melalui rekomendasi kebijakan dan program yang berorientasi pemecahan masalah; 2) UNDP sebaiknya tetap menjalankan UNDS dengan arsitektur kawasan dan kantor di berbagai negara yang sudah ada; serta 3) UNDS sebaiknya memberikan dukungan berbasis permintaan untuk membantu negaranegara dalam menghadapi situsi pandemi global COVID-19 serta pembangunan kembali masyarakat setalah pandemic (Lihat Gambar 2) (Kementerian Luar Negeri Republik Indonesia, 2020g). Tiga hal ini mewakili pandangan Indonesia yang menekankan pendekatan untuk melawan pandemi global COVID-19 dan pembangunan masyarakat yang lebih baik

dan tangguh (Kementerian Luar Negeri Republik Indonesia, 2020f).

Gambar 2. Duta Besar Mohammad Koba (pojok kiri atas) dalam pertemuan virtual ECOSOC

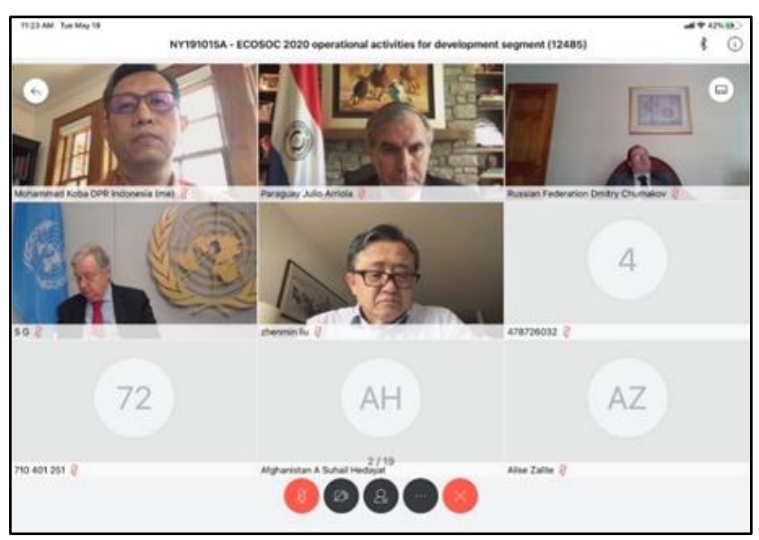

Sumber: Kementerian Luar Negeri Republik Indonesia, 2020f

Berbaga dinamika di atas memperlihatkan Indonesia sebagai salah satu negara yang menjalankan pemanfaatan TIK untuk diplomasi. Indonesia dapat dikatakan sudah menyadari transformasi digital di bidang diplomasi adalah aspek penting agar tidak tertinggal dari negara lain dan tetap relevan dengan perkembangan zaman (Kementerian Luar Negeri Indonesia, 2019b). Lebih lanjut, diplomasi digital bagi Indonesia bermanfaat untuk empat hal yaitu: 1) penyebaran pesan perdamaian, 2) alat penguatan kerja sama ekonomi, 3) alat untuk melindungi warga negara, dan 4) alat untuk memajukan pembangunan (Kementerian Luar Negeri Republik 
Indonesia, 2019b). Empat hal tersebut juga tergambarkan dalam dinamika diplomasi digital Indonesia di PBB ketika pandemi global COVID-19. Dengan kata lain, Indonesia telah memanfaatkan teknologi digital untuk meningkatkan pelayanan dan perlindungan WNI di luar negeri serta menyikapi berbagai tantangan yang muncul dalam hubungan internasional kontemporer (Kementerian Luar Negeri Republik Indonesia, 2019b).

\section{Shapiro dan Rakov (2020)} berpendapat perkembangan pandemi COVID-19 memberikan hambatan baru dalam menjalani aktivitas diplomatik. Diplomat dari berbagai negara tidak dapat bertemu tatap muka, melakukan perjalanan ke luar negeri, atau mengadakan pertemuan tingkat tinggi (Shapiro \& Rakov, 2020). Perwakilan tetap di berbagai negara tidak dapat mengoptimalkan keunggulan utama mereka yaitu bertemu penduduk setempat dan merasakan berbagai dinamika di lapangan (Shapiro \& Rakov, 2020). Setiap kantor kedutaan menjadi harus terbiasa untuk melakukan segala aktivitas secara daring (Shapiro \& Rakov, 2020). Berbagai pertemuan jarak jauh dengan konferensi video virtual untuk membahas isu internasional menjadi hal yang wajar dilakukan oleh setiap diplomat (Shapiro \&
Rakov, 2020). Shapiro dan Rakov (2020) menambahkan aktivitas diplomasi digital setidaknya perlu dilakukan oleh aktor negara hingga 12-18 bulan mendatang. Meskipun begitu, dari aktivitas PTRI untuk PBB di New York ketika pandemi global COVID-19 dapat terlihat aktor negara tetap bisa menjalankan aktivitas diplomasi secara virtual dengan optimal. Indonesia tetap melindungi WNI, mengikuti pertemuan di PBB, dan menyampaikan posisinya dalam isu-isu internasional.

\section{Kesimpulan}

Dengan dihubungkan konsep diplomasi digital, artikel ini menyimpulkan penggambaran pada bagian sebelumnya sebagai berikut. Keberadaan pandemi global COVID-19 mengubah cara Perutusan Tetap Republik Indonesia (PTRI) untuk PBB di New York dalam mengumpulkan informasi, negosiasi, dan respons terkait isu internasional menjadi virtual. Dimulai dari koordinasi dengan Kedutaan Besar dan Konsulat Jenderal Republik Indonesia di Amerika Serikat hingga pertemuan Dewan Keamanan (DK) PBB secara umum menggunakan sarana dan alat berbasis daring. Walaupun ada perubahan seperti ini, Indonesia tetap dapat menjalankan diplomasi dengan optimal. Indonesia secara digital tetap aktif 
berupaya melindungi warga negara

Indonesia (WNI) dan berpartisipasi dalam berbagai pertemuan di PBB guna mendukung upaya global mengatasi COVID-19, menjalankan pembangunan berkelanjutan, serta menjamin perdamaian dan keamanan internasional.

\section{Referensi}

Buku

Barston, R. P. (2013). Modern Diplomacy. New York: Routledge.

Bjola, C. (2016). Introduction: Making Sense of Digital Diplomacy. Dalam C. Bjola \& M. Holmes (Eds.), Digital Diplomacy: Theory and Practice (pp. 1-10). New York: Routledge.

Bjola, C. \& Kornprobst, M. (2018). Understanding International Diplomacy: Theory, Practice, and Ethics. New York: Routledge.

Gilboa, E. (2016). Digital Diplomacy. Dalam C. M. Constantinou, P. Kerr, \& P. Sharp (Eds), The SAGE Handbook of Diplomacy (pp. 540551). London: SAGE.

Heywood, A. (2011). Global Politics. New York: Palgrave.

Holmes, M. (2016a). Digital Diplomacy and International Change
Management. Dalam C. Bjola \&

M. Holmes (Eds.), Digital Diplomacy: Theory and Practice (pp. 13-32). New York: Routledge.

Holmes, M. (2016b). Conclusion: The Future of Digital Diplomacy. Dalam C. Bjola \& M. Holmes (Eds.), Digital Diplomacy: Theory and Practice (pp. 199-206). New York: Routledge.

Jönsson, C. (2012). Theorising Diplomacy. Dalam B. J. C. McKercher (Ed.), Routledge Handbook of Diplomacy and Statecraft (pp. 15-28). New York: Routledge.

Sotiriu, S. (2016). Digital Diplomacy: Between Promises and Realities. Dalam C. Bjola \& M. Holmes (Eds.), Digital Diplomacy: Theory and Practice (pp. 33-51). New York: Routledge.

\section{Internet}

GIP Digital Watch (2020). UN GGE and OEWG. Diperoleh dari https://dig.watch/processes/un-gge

Indonesiaunny. (2020a). Dalam Halaman Facebook Permanent Mission of the Republic of Indonesia to the United Nations. Diperoleh dari https://www.facebook.com/story.p 
hp?story_fbid=3325522714144110 \&id=1722596714436726

indonesiaunny. (2020b). Dalam Halaman Facebook Permanent Mission of the Republic of Indonesia to the United Nations. Diperoleh dari https://www.facebook.com/indones iaunny/videos/644808326062853/

indonesiaunny. (2020c). Dalam Halaman Facebook Permanent Mission of the Republic of Indonesia to the United Nations. Diperoleh dari https://www.facebook.com/story.p hp?story_fbid=3328319130531135 \&id=1722596714436726

indonesiaunny. (2020d). Dalam Halaman Facebook Permanent Mission of the Republic of Indonesia to the United Nations. Diperoleh dari https://www.facebook.com/story.p hp?story_fbid=3328311967198518 \&id=1722596714436726

indonesiaunny. (2020e). Dalam Halaman Facebook Permanent Mission of the Republic of Indonesia to the United Nations. Diperoleh dari https://www.facebook.com/story.p hp?story_fbid=3329513627078352 \&id=1722596714436726 indonesiaunny. (2020f). Dalam Halaman Facebook Permanent Mission of the Republic of Indonesia to the United Nations. Diperoleh dari https://www.facebook.com/story.p hp?story_fbid=3329518697077845 \&id=1722596714436726

indonesiaunny. (2020g). Dalam Halaman Facebook Permanent Mission of the Republic of Indonesia to the United Nations. Diperoleh dari https://www.facebook.com/story.p hp?story_fbid=3344955995534115 \&id=1722596714436726

indonesiaunny. (2020h). Dalam Halaman Facebook Permanent Mission of the Republic of Indonesia to the United Nations. Diperoleh dari https://www.facebook.com/story.p hp?story_fbid=3367306499965731 \&id=1722596714436726

indonesiaunny. (2020i). Dalam Halaman Facebook Permanent Mission of the Republic of Indonesia to the United Nations. Diperoleh dari https://www.facebook.com/indones iaunny/posts/3374579795905068

indonesiaunny. (2020j). Dalam Halaman Facebook Permanent Mission of the Republic of Indonesia to the United Nations. Diperoleh dari 
https://www.facebook.com/story.p hp?story_fbid=3382746941755020 \&id $=1722596714436726$

indonesiaunny. (2020k). Dalam Halaman Facebook Permanent Mission of the Republic of Indonesia to the United Nations. Diperoleh dari https://www.facebook.com/story.p hp?story_fbid=3432161996813514 \&id $=1722596714436726$

Kementerian Luar Negeri Republik Indonesia. (2019a). Keanggotaan Tidak Tetap Indonesia pada Dewan Keamanan PBB Periode 2019-2020. Diperoleh dari https://kemlu.go.id/portal/id/read/1 47/halaman_list_lainnya/keanggota an-indonesia-pada-dk-pbb

Kementerian Luar Negeri Republik Indonesia. (2019b). Indonesia Gaungkan Diplomasi Digital di Kawasan. Diperoleh dari https://kemlu.go.id/portal/id/read/5 84/berita/indonesia-calls-fordigital-diplomacy-in-the-region

Kementerian Luar Negeri Republik Indonesia. (2020a). Kebijakan Tambahan Pemerintah Indonesia Terkait Perlintasan Orang Dari dan Ke Indonesia. Diperoleh dari https://kemlu.go.id/portal/id/read/1 135/siaran_pers/kebijakantambahan-pemerintah-indonesiaterkait-perlintasan-orang-dari-danke-indonesia

Kementerian Luar Negeri Republik Indonesia. (2020b). Indonesia Sukses Loloskan Resolusi PBB Perdana Tentang Solidaritas Global Atasi COVID-19. Diperoleh dari https://kemlu.go.id/portal/id/read/1 160/berita/indonesia-successfullypasses-the-first-un-resolution-onglobal-solidarity-to-overcomecovid-19

Kementerian Luar Negeri Republik Indonesia. (2020c). Indonesia Tegaskan Prioritasnya Untuk Lindungi Penduduk Sipil, Termasuk Dari Kelaparan. Diperoleh dari https://kemlu.go.id/newyorkun/id/news/6335/indonesiareaffirms-their-priority-to-protectcivilians-including-from-hunger

Kementerian Luar Negeri Republik Indonesia. (2020d). Statement at the United Nations Security Council Briefing: Protecting Civilians affected by Conflictinduced Hunger. Diperoleh dari 
https://kemlu.go.id/newyork-

un/id/read/statement-at-the-unitednations-security-council-briefingprotecting-civilians-affected-byconflict-induced-hunger/3531/etcmenu

Kementerian Luar Negeri Republik Indonesia. (2020e). Respon dan Upaya Pemulihan dari COVID-19 di Asia-Pasifik, diperoleh dari https://kemlu.go.id/newyorkun/id/news/6661/response-andrecovery-efforts-from-covid-19-inasia-pacific

Kementerian Luar Negeri Republik Indonesia. (2020f). Indonesia Stressed on Member-Driven Approach to Fight COVID19 and Build More Resilient Societies in ECOSOC. Diperoleh dari https://kemlu.go.id/newyorkun/id/news/6759/indonesiastressed-on-member-drivenapproach-to-fight-covid19-andbuild-more-resilient-societies-inecosoc

Kementerian Luar Negeri Republik Indonesia. (2020g). ECOSOC Operational Activities Development Segment. Diperoleh dari https://kemlu.go.id/newyork- un/en/read/ecosoc-operationalactivities-developmentsegment/3658/etc-menu

Organisation for Economic Co-operation and Development. (2020). Coronavirus: The World Economy at Risk. Diperoleh dari https://www.oecdilibrary.org/economics/oecdeconomic-outlook/volume2019/issue-2_7969896b-en

Shapiro, D. B. \& Rakov, D. (2020). Will Zoomplomacy Last?. Diperoleh dari https://foreignpolicy.com/2020/05/ 18/will-zoomplomacy-last/

United Nations. (2019a). SecretaryGeneral Presents First Annual Budget in Over 45 Years to Fifth Committee, Proposing $\$ 2.87$ Billion for 2020 Focused on Strategic Priorities, Reforms. Diperoleh dari https://www.un.org/press/en/2019/ gaab4330.doc.htm

United Nations. (2019b). Transforming our world: the 2030 Agenda for Sustainable Development. Diperoleh dari https://sustainabledevelopment.un. 
org/post2015/transformingourworl d

United Nations. (2019c). Treaty on the Non-Proliferation of Nuclear Weapons (NPT). Diperoleh dari https://www.un.org/disarmament/w $\mathrm{md} /$ nuclear/npt/

United Nations. (2020a). Global Solidarity to Fight COVID-19. Diperoleh dari https://www.un.org/pga/74/2020/0 3/30/global-solidarity-to-fightcovid-19/

United Nations. (2020b). SecretaryGeneral's Appeal for Global Ceasefire. Diperoleh dari https://www.un.org/sg/en/content/s g/statement/2020-03-23/secretarygenerals-appeal-for-globalceasefire

United Nations. (2020c). Guiding Operational Activities for Development. Diperoleh dari https://www.un.org/ecosoc/en/oasqcpr

United Nations. (2020d). UN Development System Reform 101. Diperoleh dari https://reform.un.org/content/undevelopment-system-reform-101

Vieru, O., Tkhlashidze, E., Harutyunyan, A., \& Uraguchi, Z. B. (2020). Turning the Coronavirus Challenges into Opportunities.
Diperoleh dari https://www.helvetas.org/en/switze rland/how-you-can-help/followus/blog/inclusive-systems/Coronaopportunities

World Health Organization. (2020a). $Q \& A$ on Coronaviruses (COVID-19). Dirperoleh dari https://www.who.int/emergencies/d iseases/novel-coronavirus2019/question-and-answers-hub/qa-detail/q-a-coronaviruses

World Health Organization. (2020b). WHO Coronavirus Disease (COVID-19) Dashboard. Diperoleh dari https://covid19.who.int/ 